\title{
Reduction of arsenic entry into rice from arsenic contaminated soil using Pteris vittata as trap plant
}

\author{
U. Mayda ${ }^{a}$, Rasheda Yasmin Shilpi ${ }^{a}$, T. Taufique ${ }^{b}$, H. Mehraj ${ }^{c}$ and AFM Jamal Uddin ${ }^{b}$ \\ Dept. of Botany, Jahangirnagar University, Savar, Dhaka-1342, Bangladesh \\ ${ }^{b}$ Dept. of Horticulture, Sher-e-Bangla Agricultural University, Dhaka-1207, Bangladesh \\ 'The United Graduate School of Agricultural Sciences, Ehime University, 3-5-7 Tarami, Matsumaya, \\ Ehime 790-8556, Japan
}

\begin{abstract}
An experiment was conducted to reduce the entrance of arsenic on rice plant. Experiment consisted three different density of the trap plants viz. $P_{1}$ : No P. vittata (control); $P_{2}$ : four P. vittata plant per $m^{2}$ and $P_{3}$ : eight $P$. vittata plant per $m^{2}$. Inter planting of four $P$. vittata per $m^{2}$ reduced $96.24 \%$ and eight $P$. vittata per $m^{2}$ reduced $97.01 \%$ arsenic accumulation into rice. Maximum yield was found from $P_{2}(34.2 \mathrm{~g}$ per plant) which was statistically similar with $P_{3}\left(32.9 \mathrm{~g}\right.$ per plant) while minimum was found from $P_{1}(30.0 \mathrm{~g}$ per plant). Highest amount of arsenic accumulation was found from $P_{1}$ in rice grain (1.55 ppm), husk (5.57 ppm) and straw (39.78 ppm). Arsenic accumulation was found in rice grain (0.02 ppm in both $P_{2}$ and $P_{3}$ ), husk (0.60 and 0.58 ppm in $P_{2}$ and $P_{3}$ respectively) and straw (1.05 and 1.00 ppm in both $P_{2}$ and $P_{3}$ respectively). Concerning both yield of rice and arsenic concentrations in rice plant, it can be recommended to interplant four P. vittata plant per $m^{2}$ area as a trap plant to reduce arsenic entrance into rice plant from soil which can keep away of arsenic pollution in food chain.
\end{abstract}

Key words: Arsenic, rice, Pteris vittata, inter-planting and trap plant

Please cite this article as: Mayda, U., Shilpi, R. Y., Taufique, T., Mehraj, H. and Jamal Uddin, A F. M. (2015). Reduction of arsenic entry into rice from arsenic contaminated soil using Pteris vittata as trap plant. Journal of Bioscience and Agriculture Research 04(02): 60-66.

This article is distributed under terms of a Creative Common Attribution 4.0 International License

\section{Introduction}

Arsenic is a toxic metalloid. Its contamination in soil is increasing day by day in some parts of Bangladesh. Arsenic accumulation in food crops is a major concern. Rice is the staple food in Bangladesh. High level of arsenic in irrigated water and soil appears to result in higher concentration of arsenic in rice grain, husk and straw (Abedin et al., 2002; Das et al., 2004). Most of the agricultural soil is contaminated by arsenic due to the irrigation during winter season mostly in southern and western part of Bangladesh. The districts with the highest mean arsenic rice grain levels were all from southwestern Bangladesh, which are Faridpur (boro rice season) $0.51>$ Satkhira (boro) $0.38>$ Satkhira (aman rice season) $0.36>$ Chuadanga (boro) $0.32>$ Meherpur (boro) $0.29 \mu \mathrm{g} \mathrm{As} \mathrm{g}^{-1}$ (Williams et al., 2006). Dietary intake of rice grain is potentially a major arsenic exposure pathway (Smith et al., 2008) in Bangladesh while husk and straw used as the feed for the domestic birds and animal which 
cause direct effect of animal body. Consuming this animal meat arsenic comes into the human body indirectly. $P$. vittata can survive highly arsenic contaminated soil $(4000 \mathrm{ppm})$ and accumulate up to 27829.7 ppm arsenic (Mayda et al., 2014) and accumulate $23837.2 \mathrm{ppm}$ arsenic from $2000 \mathrm{ppm}$ arsenic contaminated soil (Jamal Uddin et al., 2015) into the plant body. As P. vittata can accumulate considerable amount of arsenic from contaminated soil. Thus, it would be potential to reduce the arsenic accumulation into the rice by using P. vittata as trap plant. On the hand, $P$. vittata does not require many nutrients to grow. Thus, growing $P$. vittata along with rice may not interfere (and or less interferences) with the growth and yield rice. Considering these points in view, the study was undertaken to reduce the arsenic accumulation into rice plant using P. vittata as trap plant.

\section{Materials and Methods}

Location and duration of the experiment: An experiment was conducted at Department of Horticulture of the Sher-e-Bangla Agricultural University, Dhaka-1207, Bangladesh and at the Department of Botany of the Jahangirnagar University, Savar, Dhaka-1342, Bangladesh from October 2013 to April 2014.

Arsenic contaminated soil: Arsenic was applied in the form of Arsenic trioxide $\left(\mathrm{As}_{2} \mathrm{O}_{3}\right) @ 50$ ppm at 7 days before transplanting of the rice plant.

Treatments and design: $P$. vittata was inter-planted with rice into pot as trap to mitigate arsenic accumulation into rice plant. Experiment consisted three different density of the trap plants viz. $\mathrm{P}_{1}$ : No $P$. vittata (Control); $\mathrm{P}_{2}$ : four $P$. vittata plant per $\mathrm{m}^{2}$ and $\mathrm{P}_{3}$ : eight $P$. vittata plant per $\mathrm{m}^{2}$ following completely randomized design with three replication. Trap plants were planted at the time of transplanting of rice plants.

Pot size: The pot size was $1.5 \mathrm{~m}$ in length, $0.5 \mathrm{~m}$ in width and $0.5 \mathrm{~m}$ in depth.

Data collection: Data were collected on plant height, number of tillers per plant, number of effective tillers per plant, panicle length, total number of grains per panicle, number of filled grains per panicle, number of unfilled grains per panicle, percentage of unfilled grains, 1000-grains weight, yield per plant, arsenic accumulation by rice grain, husk and straw, arsenic accumulation by $P$. vittata and reduction of arsenic accumulation in rice by $P$. vittata over control.

Chemical analysis for arsenic: Plant biomass was measured by using precision balance after drying. After growing, plants were collected and dried. After drying, samples were smashed by mortar and pastel machine. The arsenic analysis for was performed by using "Atomic Absorption Spectrometer", where use of argon for carrier gas and arsenic was melted by $925^{\circ} \mathrm{C}$; was approved by ISO organization in Bangladesh Council of Scientific Research Institute (BCSIR), Dhaka, Bangladesh.

50 times dilution: $05 \mathrm{ml}$ concentrated $\mathrm{HCl}$ was taken at $50 \mathrm{ml}$ volumetric flasks for transferring arsenic into arsenic trioxide and a little bit of distilled water was added. Then $1 \mathrm{ml}$ solution was taken very carefully from each volumetric flask to avoid bubble and $\mathrm{KI}(01 \mathrm{gm})$ wash added in solution with $150 \mathrm{ml}$ distilled water. After that 0.5 gm sample was taken in volumetric flask and mixed distilled water up to $50 \mathrm{ml}$ and solution turned into yellow color. Another volumetric flask made blank solution, where contain only $\mathrm{HCl}, \mathrm{KI}$ and distilled water for arsenic analysis.

1000 time dilution: $02 \mathrm{ml}$ solution was taken into 500 volumetric flasks, mixed with distilled water up to $500 \mathrm{ml}$ and shaken very carefully. Then, $05 \mathrm{ml}$ solution was taken into $250 \mathrm{ml}$ volumetric flask and mixed with distilled water up to $250 \mathrm{ml}$. Again, $05 \mathrm{ml}$ solution from $250 \mathrm{ml}$ solution was taken into $25 \mathrm{ml}$ volumetric flask then $2.5 \mathrm{ml} \mathrm{HCl}$ and $2.5 \mathrm{ml} \mathrm{KI}$ was added and mixed distilled water, shaking was done very smoothly until turn it into yellow color. Standard solution arsenic was added with $\mathrm{HCl} \mathrm{2,} \mathrm{5,}$ $10,15,20$ ppb respectively. 
$\mathbf{5 0 0 0}$ time dilution: Similar to the 1000 time dilution. But $04 \mathrm{ml}$ solution was taken in case of $2 \mathrm{ml} .05$ $\mathrm{ml} \mathrm{HCl}$ and $\mathrm{KI}$ was added into $5000 \mathrm{ml}$ volumetric flask, solution was made into $25 \mathrm{ml}$ and $05 \mathrm{ml}$ was taken in flask.

Statistical analysis: Data were statistically analyzed using MSTAT-C computer package programme. Difference between treatments was assessed by Least Significance Difference (LSD) test at 5\% level of significance (Gomez and Gomez, 1984).

\section{Results and Discussion}

Plant height: Plant height of rice showed significant variation among the treatments viz. $\mathrm{P}_{1}, \mathrm{P}_{2}$ and $\mathrm{P}_{3}$. Tallest plant was found from $\mathrm{P}_{1}(87.1 \mathrm{~cm})$ whereas shortest from $\mathrm{P}_{3}(80.8 \mathrm{~cm})$ at harvest (Figure 1). Tallest $(96.64 \pm 0.73 \mathrm{~cm})$ and shortest $(82.66 \pm 7.6 \mathrm{~cm})$ plant were found in 0.5 and $4.0 \mathrm{mg} / \mathrm{L}$ arsenic amended plots (Azad et al., 2013). Abedin et al. (2002) also found that arsenic contaminated irrigation water significantly reduced the plant height.

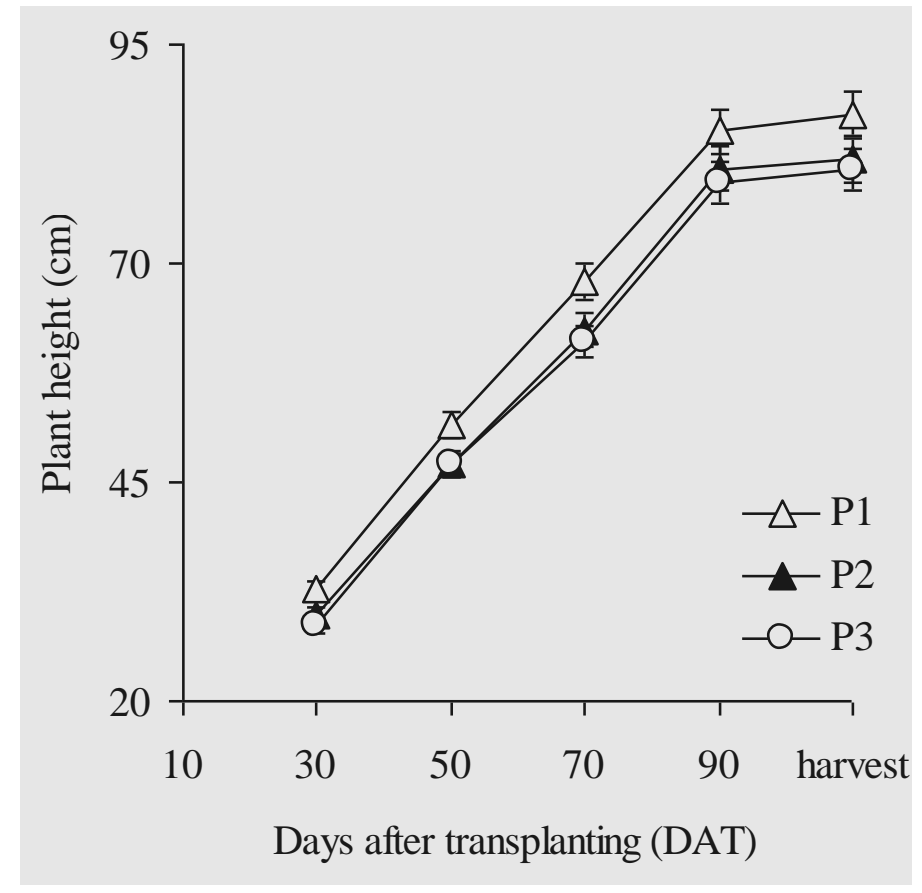

Figure 01. Response of rice to different density of trap plant (P. vittata) for arsenic on plant height

Number of tillers: Number of tillers showed a significant variation among the treatments. Maximum number of tiller was found from $\mathrm{P}_{1}$ (12.3 per plant) while minimum from $\mathrm{P}_{3}$ (11.7 per plant) which was statistically identical with $\mathrm{P}_{2}$ (11.9 per plant) at harvest (Table 01). When plants are exposed to excess arsenic either in soil or in solution culture, they exhibit toxicity symptoms like decrease in plant height (Abedin et al., 2002).

Number of effective tillers: Maximum number of effective tillers was found from $\mathrm{P}_{2}$ (11.7 per plant) which was statistically identical with $\mathrm{P}_{3}$ (11.4 per plant) whereas minimum from $\mathrm{P}_{1}$ (11.0 per plant) (Table 01). BRRI-29 showed more number of effective tillers per plant than control in $15 \mathrm{ppm}$ arsenic concentration (Huda et al., 2009) while Abedin et al. (2002) observed that tiller number was reduced significantly due to arsenic concentration in irrigation water.

Panicle length: Panicle length of rice was varied significantly among the treatments. Longest panicle was found from $\mathrm{P}_{1}(24.1 \mathrm{~cm})$ which was statistically similar with $\mathrm{P}_{2}(23.8 \mathrm{~cm})$ whereas shortest from 
$\mathrm{P}_{3}(23.4 \mathrm{~cm})$ (Table 01). This result indicated that without Pteris vittata BRRI-29 uptake arsenic showed longest panicle length. Longest panicle $(24.20 \pm 0.69 \mathrm{~cm})$ and shortest panicle $(21.83 \pm 0.84$ $\mathrm{cm}$ ) were found in control and $4.0 \mathrm{mg} / \mathrm{L}$ arsenic treated plot (Azad et al., 2012).

Total number of grains: There was no significant variation was observed among the treatments in terms of total number of grains. However, the total number of grains was 142.7 per plant, 143.0 per plant and 142.9 per plant in $\mathrm{P}_{1}, \mathrm{P}_{2}$ and $\mathrm{P}_{3}$ respectively (Table 01). Increasing the concentration of arsenate in irrigation water significantly decreased the number of grains (Abedin et al., 2002).

\section{Table 01. Response of rice to different density of trap plant (P. vittata) for arsenic on some yield related attributes $x$}

\begin{tabular}{lcrrrr}
\hline Treatments & $\begin{array}{c}\text { Number of } \\
\text { tillers/plant at } \\
\text { harvest }\end{array}$ & $\begin{array}{c}\text { Number of } \\
\text { effective } \\
\text { tillers/plant }\end{array}$ & $\begin{array}{c}\text { Panicle length } \\
\text { (cm) }\end{array}$ & $\begin{array}{c}\text { Total number of } \\
\text { grains/panicle }\end{array}$ \\
\hline $\mathrm{P}_{1}$ & $12.3 \mathrm{a}$ & $11.0 \mathrm{~b}$ & $24.1 \mathrm{a}$ & $142.7 \mathrm{a}$ \\
$\mathrm{P}_{2}$ & $11.9 \mathrm{~b}$ & $11.7 \mathrm{a}$ & 23.8 ab & $143.0 \mathrm{a}$ \\
$\mathrm{P}_{3}$ & $11.7 \mathrm{~b}$ & $11.4 \mathrm{a}$ & $23.4 \mathrm{~b}$ & $142.9 \mathrm{a}$ \\
\hline$L S D 0.05$ & 0.5 & 0.7 & 1.5 & 1.9 \\
$C V \%$ & 2.8 & 2.7 & 1.4 & 0.6 \\
\hline
\end{tabular}

xIn a column means having similar letter (s) are statistically identical and those having dissimilar letter (s) differ significantly as per 0.01 level of probability

Number of filled grains: Number of filled grains varied significantly among the treatments. Maximum number of filled grains was found from $\mathrm{P}_{2}$ (135.0 per panicle) which was statistically identical with $\mathrm{P}_{3}$ (134.4 per panicle) whereas minimum $\mathrm{P}_{1}$ (127.0 per panicle) (Table 02). Number of panicle was found to be decreased significantly with the increase of soil arsenic concentrations (Rahman et al., 2004). Rice plant grown in arsenic contaminated soil may cause the reduction of number of filled grain per panicle along with other factors.

Number and percentage of unfilled grains: Maximum number of unfilled grains was found from $\mathrm{P}_{1}$ (15.7 per panicle) while minimum from $\mathrm{P}_{2}$ (8.0 per panicle) which was statistically identical with $\mathrm{P}_{3}$ (8.6 per panicle) (Table 02). This result indicated that arsenic contamination in soil increase the number of unfilled grain but $P$. vittata can help to reduce arsenic accumulation into rice. Plant might be reduced the number of unfilled grains. P. vittata uptake high amount of arsenic from soil and accumulate arsenic into their fronds. Most of the arsenic was accumulated in the fronds (i.e., a frond is a large, divided leaf of fern) of $P$. vittata (89-93\%), so metal uptake by $P$. vittata can be used as a costeffective amendment for phytoremediation of arsenic and metal polluted soils (Ma et al., 2001). Maximum unfilled grains were found from $\mathrm{P}_{1}$ (11.0\%) while minimum from $\mathrm{P}_{2}$ (5.6\%) which was statistically identical with $\mathrm{P}_{3}(6.0 \%)$ (Table 02$)$. Addition of arsenic significantly reduced tillering (Khan et al., 2010) and increasing the concentration of arsenate in irrigation water significantly decreased the number of filled grains (Abedin et al., 2002).

1000-grains weight: There was no significant variation was observed among the treatments in terms of 1000-grains weight. However, maximum 1000-grains weight was found from $\mathrm{P}_{1}(21.5 \mathrm{~g})$ whereas minimum from $\mathrm{P}_{2}$ and $\mathrm{P}_{3}(21.3 \mathrm{~g}$ ) (Table 02). Presence of arsenic arsenate at a higher concentration in irrigation water significantly reduced 1000-grain weight (Abedin et al., 2002). 1000-grain weights of rice were decreased with increasing of arsenic in irrigation water but the differences were not statistically significant (Azad et al., 2012).

Yield: Yield of each plant was varied significantly among the treatments. Maximum yield was found from $\mathrm{P}_{2}(34.2 \mathrm{~g} / \mathrm{plant})$ which was statistically identical with $\mathrm{P}_{3}(32.9 \mathrm{~g} / \mathrm{plant})$ while minimum from $\mathrm{P}_{1}$ (30.0 per plant) (Table 02). Grain yield of rice was decreased as the level of arsenic addition was increased, and the yield was reduced drastically with the $30 \mathrm{mg} \mathrm{As} / \mathrm{kg}$ addition (Hossain et al., 2009). From the experiment, it can be stated that using P. vittata reduces the arsenic toxicity from the soil and increase the yield of each plant. P. vittata uptake huge amount of arsenic from soil and accumulate 
arsenic into their fronds. Contaminated site with $38.9 \mathrm{mg} / \mathrm{kg}$ of arsenic in the soil, the fern's fronds had $7526.0 \mathrm{mg} / \mathrm{kg}$ of arsenic and under experimental conditions where soil was loaded with arsenic; fern accumulated $22630.0 \mathrm{mg} / \mathrm{kg}$ (2.3\%) of the heavy metal (Singh and Ma, 2006).

\section{Table 02. Response of rice to different density of trap plant (P. vittata) for arsenic on some yield related attributes and yield $x$}

\begin{tabular}{|c|c|c|c|c|c|}
\hline Treatments & $\begin{array}{l}\text { Number of filled } \\
\text { grains/panicle }\end{array}$ & $\begin{array}{l}\text { Number of unfilled } \\
\text { grains/panicle }\end{array}$ & $\begin{array}{c}\text { Unfilled } \\
\text { grains (\%) }\end{array}$ & $\begin{array}{c}1000- \\
\text { grains } \\
\text { weight }(\mathrm{g})\end{array}$ & $\begin{array}{c}\text { Yield } \\
\text { (g)/plant }\end{array}$ \\
\hline $\mathrm{P}_{1}$ & $127.0 \quad b$ & $15.7 \quad \mathrm{a}$ & $11.0 \quad \mathrm{a}$ & $21.5 \mathrm{a}$ & 30.0 \\
\hline $\mathrm{P}_{2}$ & $135.0 \quad \mathrm{a}$ & 8.0 & 5.6 & 21.3 & 34.2 \\
\hline $\mathrm{P}_{3}$ & 134.4 & 8.6 & $6.0 \mathrm{~b}$ & 21.3 & 32.9 \\
\hline LSD 0.05 & 2.2 & 2.7 & 1.8 & 0.5 & 1.4 \\
\hline CV\% & 0.8 & 11.2 & 10.5 & 1.1 & 1.3 \\
\hline
\end{tabular}

xIn a column means having similar letter (s) are statistically identical and those having dissimilar letter (s) differ significantly as per 0.01 level of probability

Arsenic accumulation: Arsenic accumulation was varied significantly among the treatments by rice grain, husk and straw. Maximum arsenic accumulation was found from $\mathrm{P}_{1}$ (1.55 ppm in grain, 5.57 ppm in husk and 39.78 ppm in straw) whereas minimum from $\mathrm{P}_{3}(0.02 \mathrm{ppm}$ in grain, $0.58 \mathrm{ppm}$ in husk and $1.00 \mathrm{ppm}$ in straw) which was statistically identical with $\mathrm{P}_{2}(0.02 \mathrm{ppm}$ in grain, $0.60 \mathrm{ppm}$ in husk and $1.05 \mathrm{ppm}$ in straw) (Table 03). On the contrary, Pteris vittata used as trap to arsenic was accumulated arsenic 45.13 ppm by $\mathrm{P}_{2}$ and 45.49 ppm by $\mathrm{P}_{3}$ (Table 3). $\mathrm{P}_{1}$ and $\mathrm{P}_{2}$ were reduced $96.24 \%$ and $97.01 \%$ arsenic accumulation into rice over $\mathrm{P}_{1}$ (control) (Table 03). The arsenic concentrations in rice grain were varied widely depending on the cultivars, as status of soil and irrigation water (Abedin et al. 2002, Norton et al. 2009a and 2009b). Pteris vittata uptake high amount of arsenic. It revealed that $\mathrm{P}_{1}$ and $\mathrm{P}_{2}$ treated BRRI-29 rice grain accumulate only low amount of arsenic and reduction of arsenic accumulation into rice is $96.24 \%$ and $97.01 \%$. Arsenic content in rice grain ranged from 0.80 to $1.18 \mathrm{mg} / \mathrm{kg}$ in unplanted control where as it was 0.59 to $0.81 \mathrm{mg} / \mathrm{kg}$ after phytoextraction by Pteris vittata in one growing cycle and 0.35 to $0.61 \mathrm{mg} / \mathrm{kg}$ after phytoextraction with two successive growing cycles (Mandal et al., 2012). Ferns grew well and took up arsenic from soils. Fern biomass ranged from 24.8-33.5 g/plant after 4 months of growth but was reduced in the subsequent harvests and frond arsenic concentrations ranged from $66.0-6151.0 \mathrm{mg} / \mathrm{kg}, 110.0-3056.0 \mathrm{mg} / \mathrm{kg}$ and $162.0-2139.0$ $\mathrm{mg} / \mathrm{kg}$ from the first, second and third harvest respectively; subsequently $P$. vittata reduced soil arsenic by $6.4-13.0 \%$ after three harvests (Ma et al., 2008). Straw yield was decreased significantly with arsenic addition in irrespective of season, year, method and level of arsenic application (Khan $e t$ al., 2010). The highest straw yield (39.07 $\pm 4.08 \mathrm{~g})$ and lowest straw yield (27.01 $\pm 6.74 \mathrm{~g})$ were found in $0.5 \mathrm{mg} / \mathrm{L}$ and $4.0 \mathrm{mg} / \mathrm{L}$ arsenic treatment (Azad et al., 2012). Pteris vittata uptakes high amounts of arsenic in their fronds (Mandal et al., 2012). It was observed that arsenic uptake by rice straw decreased significantly in arsenic ameliorated soil by two harvests of Pteris vittata. The arsenic uptake of rice root followed a similar trend as that of straw uptake. These findings differ from the results of studies using other ferns. Arsenic concentrations in the ladder brake fern fronds increased as more water soluble arsenic became available to the plant ( $\mathrm{Tu}$ and $\mathrm{Ma}, 2002$ ) and concentrations of arsenic in both fronds and roots of $P$. vittata, $P$. cretica, . longfoila and P. umbrosa increased linearly with increasing additions of substrate arsenic concentrations (Zhao, 2002). Therefore, the significant accumulation of arsenic into the roots of the marsh fern and the non-significant arsenic accumulation in fronds are maybe the result of small amounts of arsenic becoming stored in vacuoles of the root cells and later being released from the vacuoles of back into the back into the plant (Ponyton et al., 2004). From the study, it was found that $P$. vittata had significant effect on growth and yield of rice on arsenic contaminated soil. Bioaccumulation factors for $P$. vittata after exposure to soil arsenic levels less than $400 \mathrm{mg} / \mathrm{kg}$. High bioaccumulation factors can be an indication of strong phytoremediation potential (Wei et al., 2006). Arsenic had a significant effect upon arsenic accumulation in rice but trapping arsenic through $P$. vittata. 
Table 03. Response of rice to different number $P$. vittata as trap for arsenic on arsenic accumulation $x$

\begin{tabular}{lrrrrrrrc}
\hline \multirow{2}{*}{ Treatments } & \multicolumn{5}{c}{ Arsenic accumulation (ppm) by } & \multirow{2}{*}{$\begin{array}{c}\text { Reduction (\%) of arsenic } \\
\text { accumulation into rice }\end{array}$} \\
\cline { 2 - 6 } & rice grain & rice husk & rice straw & P. vittata & \\
\hline $\mathrm{P}_{1}$ & 1.55 & $\mathrm{a}$ & 5.57 & $\mathrm{a}$ & 39.78 & $\mathrm{a}$ & - & - \\
$\mathrm{P}_{2}$ & 0.02 & $\mathrm{~b}$ & 0.60 & $\mathrm{~b}$ & 1.05 & $\mathrm{~b}$ & 45.13 & 96.24 \\
$\mathrm{P}_{3}$ & 0.02 & $\mathrm{~b}$ & 0.58 & $\mathrm{~b}$ & 1.00 & $\mathrm{~b}$ & 45.49 & 97.01 \\
\hline LSD 0.05 & 0.07 & 0.16 & 1.12 & & \\
CV\% & 6.44 & 3.14 & 3.53 & & \\
\hline
\end{tabular}

xIn a column means having similar letter (s) are statistically identical and those having dissimilar letter (s) differ significantly as per 0.01 level of probability

\section{Conclusion}

It was found that rice plant grown with $P$. vittata accumulate only $0.02 \mathrm{ppm}$ arsenic in grain while 1.55 ppm arsenic accumulation was found in grain without $P$. vittata. So, it can be stated that $P$. vittata might be acted as the trap plant and reduce the arsenic accumulation into rice about 96.24-97.01\%. Further experiment should be conducted on various arsenic contaminated areas with different intercrop density to clarify and strengthen the findings of the study.

\section{Acknowledgements}

The experiment was conducted as thesis work for the partial fulfillment of mater degree by the first author U. Mayda. Authors are highly grateful to Bangladesh Council of Scientific Research Institute (BCSIR), Dhaka, Bangladesh for analyzing the samples. This experiment was supported and funded by supervisors of the work.

\section{References}

[1]. Abedin, M. J., Feldmann, J. and Meharg, A. A. (2002). Uptake Kinetics of Arsenic Species in Rice Plants. Plant Physiology, 128: 1120-1128.

[2]. Azad, M., Monda, A., Hossain, I. and Moniruzzaman, M. (2013). Experiment for Arsenic Accumulation into Rice Cultivated with Arsenic Enriched Irrigation Water in Bangladesh. American Journal of Environmental Protection, 1(3): 54-58.

[3]. Das, H. K., Mitra, A. K., Sengupta, P. K., Hossain, A., Islam, F. and Rabbani, G. H. (2004). Arsenic concentrations in rice, vegetables, and fish in Bangladesh. Cell Mol. Life Sci., 57: 779-95.

[4]. Gomez, K. A. and Gomez, A. A. (1984). Statistical Procedures for Agricultural Research. 2nd edn. John Wiley and Sons. New York.: 680.

[5]. Hossain, M. B., Jahiruddin, M., Leoppert, R. H., Panaullah, G. M., Islam, M. R. and Duxbury, J. M. (2009). The effect of iron plaque and phosphorus on yield and arsenic accumulation. Plant Soil, 317: 167-176.

[6]. Huda, A., Islam M. R., Jahiruddin, M. and Hossain, M. (2009). Effects of elevated soil arsenic on growth, yield and arsenic concentration of rice. Bangladesh Res. Pub. J., 2(4): 661-666.

[7]. Jamal Uddin, A. F. M., Manirul, M. I., Mayeda, U., Roni, M. Z. K. and Mehraj, H. (2015). Evaluation of Pteris vittata as trap plant to mitigate arsenic from soil. J. Sci. Technol. Environ. Inform., 1(2): 7580.

[8]. Khan, M. A., Stroud, J. L., Zhu, Y. G., McGrath, S. P. and Zhao, F. J. (2010). Arsenic bioavailability to rice is elevated in Bangladeshi paddy soils. Environ. Sci. Technol., 44: 8515-8521.

[9]. Ma, J. F., Yamaji, N., Mitani, N., Xu, X. Y., Su, Y. H., McGrath, S. P. and Zhao, F. J. (2008), Transporters of arsenite in rice and their role in arsenic accumulation in rice grain. PNAS, 105: 9931-9935. 
[10]. Ma, L. Q., Komar, K. M., Tu, C., Zhang, W., Cai, Y. and Kennelley, E. D. (2001). A fern that hyperaccumulates arsenic. Nature, 409: 579.

[11]. Mandal, A., Purakayastha, T. J., Patra, A. K. and Sanyal, S. K. (2012). Phytoremidiation of arsenic contaminated soil by Pteris vittata L. II Effect on arsenic uptake and rice yield. International Journal of Phytoremediation, 14: 621-628.

[12]. Mayda, U., Akond, M. A., Manirul, M. I., Mehraj, H. and Jamal Uddin, A. F. M. (2014). Mitigation of soil arsenic by phytoremediation process. Int. J. Bus., Soc. and Sci. Res., 1(02): 87-94.

[13]. Norton, G. J., Duan, G., Dasgupta, T., Islam, M. R., Lei, M., Zhu, Y., Deacon, C. M., Moran, A. C., Islam, S., Zhao, F. J., Stroud, J. L., Mcgrath, S. P., Feldmann, J., Feldmann, J., Price, A. H., and Meharg, A. A. (2009b). Environmental and genetic control of arsenic accumulation and speciation in rice grain: comparing a range of common cultivars grown in contaminated sites across Bangladesh, china and India. Environmental Science \& Technology, 43: 8381-8386.

[14]. Norton, G. J., Islam, M. R., Deacon, C. M., Zhao, F. J., Stroud, J. L., Mcgrath, S. P., Islam, S., Jahiruddin, M., Feldmann, J., Price, A. H. and Meharg, A. A. (2009a), Identification of low inorganic and total grain arsenic rice cultivars from Bangladesh. Environmental Science \& Technology, 43: 60706075.

[15]. Ponyton, C. Y., Huang, J. W., Blaylock, M. J., and Elless, M. P. (2004). Mechanisms of arsenic hyperaccumulation in Pteris species: root As influx and translocation. Planta, 219: 1018-1088.

[16]. Rahman, M. A., Rahman, M. M., Miah, M. A. M. and Khaled, H. M. (2004). Influence of soil arsenic concentrations in rice (Oryza sativa L.). J. Sub-trop. Agric. Res. Dev., 2: 24-31.

[17]. Singh, N. and Ma, L. Q. (2006). Arsenic speciation, and arsenic and phosphate distribution in arsenic hyperaccumulator Pteris vittata L. and non-hyperaccumulator Pteris ensiformis L. Environ. Pollut., 141(2): 238-46.

[18]. Smith, E., Juhasz, A. L., Weber, J. and Naidu, R. (2008). Arsenic uptake and speciation in rice plants grown under greenhouse conditions with arsenic contaminated irrigation water. Science of the Total Environment, 392(2-3): 277-283.

[19]. Tu, C., and Ma, L. Q. (2002). Effect of Arsenic concentrations and Forms on Arsenic Uptake by Hyperaccumulator Ladder Brake Fern. Journal of Environmental Quality, 31(2): 641-147.

[20]. Wei, C.Y., Sun, X., Wang, C. and Wang, W. Y. (2006). Factors influencing arsenic accumulation by Pteris vittata: A comparative field study at two sites. Plant Physiol., 130: 1552-1561.

[21]. Williams, P. N., Islam, M. R., Adomako, P. N., Raab, A., Hossain, S. A., Zhu, Y. G., Feldmann, J. and Meharg, A. A. (2006). Increase in Rice Grain Arsenic for Regions of Bangladesh Irrigating Paddies with Elevated Arsenic in Groundwaters. Environ. Sci. Technol., 40: 4903-4908.

[22]. Zhao, F. J., Dunham, S. J. and McGrath, S. P. (2002). Arsenic hyperaccumulation by different fern species. New Phytol. 156: 27-31. 